\title{
Siyasal Katılma Bağlamında Belediye Meclis Toplantılarına Yurttaş Katılımı Üzerine Bir Araştırma
}

\author{
A Study of Citizen Participation in Municipality Council Meetings in the Context of \\ Political Participation
}

\author{
Özer Köseoğlu' $\odot$, Abdulkadir Aksoy² $\odot$, Ömer Faruk Köktaş ${ }^{3} \odot$
}

Öz

Belediye meclis toplantıları oy hakkı olmadan yurttaşların katılımına açıktır. Bu yönüyle, belediye meclis toplantılarına katılmak, yerel seçimlerde oy vermek ya da siyasi parti üyesi olmak gibi geleneksel katılım yollarından farklı bir davranıştır. Bu makale kentsel politikaların yapııması süreçlerine katılım yolları bağlamında belediye meclis toplantılarına dışarıdan katılan yurttaşların demografik özelliklerini, toplantılara katılım sıklıklarını ve katılım nedenlerini incelemektedir. Ayrıca katılımcıların yerel demokrasi algıları ve siyasal katılma yolları hakkındaki görüşleri analiz edilmektedir. Bu amaçla araştırmacılar bir kentteki büyükşehir ve dört büyükşehir ilçe belediyesinin meclis toplantılarını dokuz ay boyunca yerinde izlemiştir. Bu toplantılardan katılımcı gözlem ve anket yöntemiyle veriler toplanmış ve analiz edilmiştir. Böylece katılımcıların sosyo-demografik profili çıkarılmış, yerel demokrasi ve siyasal katılmayla ilgili görüşleri belirlenmiştir.

\section{Anahtar Kelimeler \\ Siyasal Katılma, Belediye Meclisi, Kentsel Politikalar}

\begin{abstract}
In Turkey, municipal council meetings are open to the participation of ordinary citizens without them needing to have the right to vote. Therefore, involvement in council meetings is a divergent participation behavior compared to voting in local elections or joining a political party. This study investigated the demographic traits, participation frequency, and motives of citizens who engage with municipal councils in the context of political engagement in urban policymaking. Moreover, their perceptions of local democracy and their views on the modes of political participation were analyzed. To achieve this, we monitored one metropolitan city council and four district municipalities in one city. We collected qualitative and quantitative data from these meetings through participatory observation and survey methods. Thus, we revealed the socio-demographic profile of the participating citizens and outlined their views on local democracy and political participation.
\end{abstract}

Keywords

Political Participation, Municipal Council, Urban Policy

1 Sorumlu Yazar: Özer Köseoğlu (Doç. Dr.), Sakarya Üniversitesi, Siyasal Bilgiler Fakültesi Siyaset Bilimi ve Kamu Yönetimi Bölümü, Sakarya, Türkiye. E-posta: ozerk@sakarya.edu.tr ORCID: 0000-0003-1277-8410

2 Abdulkadir Aksoy (Dr.), Gaziantep Üniversitesi, İktisadi ve İdari Bilimler Fakültesi Siyaset Bilimi ve Kamu Yönetimi Bölümü, Gaziantep, Türkiye. E-posta: aaksoy@gantep.edu.tr ORCID: 0000-0001-9573-5269

3 Ömer Faruk Köktaş (Arş. Gör.), Sakarya Üniversitesi, Siyasal Bilgiler Fakültesi Siyaset Bilimi ve Kamu Yönetimi Bölümü, Sakarya, Türkiye. E-posta: ofkoktas@sakarya.edu.tr ORCID: 0000-0003-3533-9883

Attf: Koseoglu, O., Aksoy, A. ve Koktas, O. F. (2021). Siyasal Katılma Bağlamında Belediye Meclis Toplantlarına Yurttaş Katılımı Üzerine Bir Araştirma. SiYASAL: Journal of Political Sciences, 30(1), 65-88. http://doi.org/10.26650/siyasal.2021.30.1.0039 


\section{Extended Summary}

Political participation addresses public actions that aim to influence political decisions and the policymaking processes of divergent organs and bodies of government, such as voting for elections to determine the distribution of parliamentary seats or in a municipal council, participating in deliberative workshops for formulating a policy, or involvement in protests and demonstrations to influence a policy agenda. Typologies of participation vary in the relevant literature and public participation actions are frequently aligned along a spectrum or ladder. We installed a typology used frequently in literature and considered every genre of participation per se, rather than arranging them in a hierarchical relationship along a spectrum or a ladder. In this way, our participation scheme included information, consultations, and active participation.

This study focused specifically on citizen engagement in urban policy. As a part of urban politics, policymaking at the city level addresses courses of action or inaction by certain officials when addressing a policy problem on an urban scale. Urban policymaking was assumed to be a cyclical process composed of sequential stages. We adopted a policy process model that contained agenda-setting, formulation, implementation, monitoring, and evaluation stages to depict the relationships between types of participation and policy stages.

Our legal and institutional analysis revealed several participation types and methods related to different policy stages in municipalities in Turkey, i.e., the right to information, voluntarily joining in the distribution of local public services, Local Agenda 21 projects, and city councils. However, this study focused on the participation of ordinary citizens in municipality council meetings to become informed about council activities, policies, and decisions. This type of participative action resembles the activities of what Milbrath and Goel (1977) termed as "spectators" who eye political discussions, follow political incidents, and maintain information about daily politics. Participating in municipality council meetings seemed to be important for their political education. Getting information about urban policymaking could also influence their future participation behavior.

According to literature, there is a lack of research on citizen engagement in municipality councils. In this context, this study investigated the demographic traits, participation frequency, and motives of citizens involved in municipal councils. Moreover, their perceptions of local democracy and their views on the modes of political participation were analyzed. To achieve this, we attended and monitored five different city councils in Sakarya province for over nine months (from March to November 2018). We collected qualitative and quantitative data from these meetings using participatory observation and survey methods.

Our evidence indicated that participants were mostly middle-aged, highly educated, had an average income, were settled in the city, and self-employed. Participants were predominantly male and frequently attended council meetings. Their interest in local and national politics was high, and they voted regularly in national and local elections. Most of them had a party affiliation.

Citizens involved in council meetings generally intend to follow the council's agenda or gain knowledge of municipal operations and decisions. Consequently, we suggested that the timings of monthly meetings, items on the agenda, and summaries of decisions 
should be disseminated to all city residents using digital and mobile technologies to encourage citizens' interest in council meetings.

Most of the participants did not support the idea of the appointment of mayors and councilors in municipalities and thought that councils should have a critical role in the enhancement of democratic culture. The evidence indicates that citizens involved in council meetings have a strong perception of local democracy. Moreover, the legitimation of the elected bodies of the municipality was a priority in the eyes of the participants.

Participants had a strong expectation of active participation methods such as referenda and participative budgeting. As a result, we suggested that new mechanisms that support active participation might improve the democratic culture at the local level. In conclusion, the survey data gathered indicated that participants were not just "spectators," but also potential "gladiators" who have a potential to actively participate in politics. 


\section{Siyasal Katılma Bağlamında Belediye Meclis Toplantılarına Yurttaş Katılımı Üzerine Bir Araştırma}

Genel olarak siyasal katılma yurttaşların ulusal veya yerel düzeyde yönetenlerin kompozisyonunu belirlemek, siyasal kararları ve politikaları kendi çıkarları doğrultusunda etkilemek amacıyla başvurdukları yollardır (Hague ve ark., 2016: 217). Siyasal katılma ulusal veya yerel seçimlerde oy vermek, aday olmak veya siyasi partiye üye olmak gibi davranışları kapsadığı kadar politika gündemini etkilemek için gerçekleştirilen gösteri ve mitinglerde yer almak, politika formülasyonu için düzenlenen çalıştay veya müzakere toplantılarına dahil olmak ya da referandumda oy vermek gibi çok farklı yol ve yöntemlerden oluşmaktadır.

Katılma yolları çeşitli tipolojiler altında tasniflenmektedir. $\mathrm{Bu}$ bağlamda siyasal katılmanın bilgilenme veya bilgi edinme, danışma, müzakere ve aktif katılım gibi farklı boyutlarından söz edilebilir. Bu çalışmada katılmanın diğger boyutlarına göre literatürde nispeten daha az üzerinde durulan bilgi edinmeye dayalı katılım davranışı konu edilmektedir. Siyasal gündemi takip etmek, karar alma süreçleri hakkında bilgilenmek, siyasal tartışmaları izlemek ve siyasal olayları yerinde gözlemlemek gibi katılım türleri bilgi edinmeye dayanır.

Siyasal katılmayla ilgili araştırmalar, oy kullanma dışındaki aktif katılım biçimlerine sınırlı sayıda katılımcının ilgi gösterdiğini ortaya koymaktadır. Aktif olarak katılan az sayıdaki bireyin dışında geniş bir izleyici kitlesinin gözlemci olarak siyasal süreçlere katıldığı görülmektedir. Siyasal olayları izlemek, internet ve sosyal medya yoluyla gündemi takip etmek, siyasal faaliyetlere ilgi göstermek ve tartışmalara katılmak gibi eylemler giderek daha yaygın hale gelmektedir (Hague ve ark., 2016: 216). Bu araştırmanın konusunu oluşturan belediye meclis toplantılarına gündemi takip etmek ve bilgi edinmek gibi amaçlarla katılan yurttaşların durumu da böyle bir katılım davranışına örnek oluşturmaktadır.

$\mathrm{Bu}$ bağlamda, makalede halkın katılımına açık olan belediye meclis toplantılarına dışarıdan katılan yurttaşların demografik özellikleri, yerel demokrasi algıları ve siyasal katılma düzeylerine ilişkin görüşleri araştırılmaktadır. 2018 yılı içinde 9 ay boyunca bir büyükşehir belediyesi ve kent merkezinde bulunan dört büyükşehir ilçe belediyesinin meclis toplantıları katılımcı gözlem yöntemiyle izlenmiştir. Toplantılara dışarıdan katılan yurttaşlar ile görüşülerek yüz yüze anket yöntemiyle veri toplanmıştır. Anketler SPSS 22 programına kodlandıktan sonra betimsel analizler yapılarak sonuçlar raporlanmıştır. Ayrıca açık uçlu olan sorular için kodlama yapılmış ve içerik analizleri gerçekleştirilmiştir.

Çalışmanın birinci bölümünde kamu politikası yapımının farklı aşamalarında siyasal katılımın gerçekleşme biçimleri kavramsallaştırılmaktadır. İkinci bölümde makalenin odak noktasını oluşturan belediye meclislerinin kentsel politika yapımındaki rolü ve işlevleri incelenmektedir. Çalışmanın ampirik kısmını oluşturan son bölümünde ise farklı belediye meclislerine katılan yurttaşların demografik özellikleri, yerel demokrasi algıları ve siyasal katılıma ilişkin görüşleri analiz edilmektedir.

\section{Siyasal Katılmanın Farklı Boyutları ve Yerel Yönetimler}

Demokrasi, teorik olarak, halkın tercihlerinin toplamının, toplumun bütününe yönelik bağlayıcı kararlara dönüştüğü bir siyasal düzeni ifade eder. Kamusal tercihlerin hangi yönde oluştuğunu belirleyebilmek ve bu tercihleri meşru zeminde kolektif kararlara 
dönüştürebilmek için yurttaşların taleplerini, bilgi akışını ve gerekli müzakere ortamını hayata geçirecek mekanizmaların varlığı önemlidir (Dalton ve Klingemann, 2011: 332). Siyasal katılma, hükümetlerin eylemlerini doğrudan veya dolaylı olarak etkileme niyetiyle sivil bireyler tarafından girişilen her türlü faaliyet olup toplumun ilgi, ihtiyaç ve değerlerinin siyasal ve yönetsel kararlara dahil edildiği bir süreçtir (Creighton, 2005: 7). $\mathrm{Bu}$ yönüyle katılma, bireyler veya toplulukların muhtemel politika sonuçlarını etkilemek için giriştikleri siyasal eylemleri kapsar. Bu ise seçimlerde oy vermeden gösteri ve mitinglerde yer almaya kadar çok geniş bir yelpazede gerçekleşir (Schlozman, 2010: 1260). Katılım davranışı genellikle bilgi verme boyutunda olduğu gibi pasif ya da karar verme süreçlerine dahil olma örneğindeki gibi aktif eylemleri içerir.

Siyasal katılma eylemleri genellikle en zayıftan en etkili katılım biçimine doğru bir düzlem üzerine yerleştirilir. Katılıma ilişkin bu klasik görüş katılma ve katılmama eylemini sekiz basamaklı bir merdiven metaforu ile ele alan Sherry Arnstein'e dayanır. Arnstein'in merdiveninde en alt basamakta manipülasyon ve terapiden oluşan katılmama (non-participation) düzeyleri bulunur. Orta basamaklarda yer alan bilgi verme, danışma ve teskin etme ise paydaşların seslerinin duyulmasını sağlayan katılım yollarıdır. Merdivenin son üç basamağında ise yurttaşların karar verme sürecinde güçlü olduğu işbirliği, yetki devri ve yurttaş kontrolü yer almaktadır. Arnstein'e göre (1969: 217), her bir basamak yurttaşların politika sonuçları üzerindeki gücüne işaret etmektedir. Üst basamaklara doğru çıkıldıkça yurttaşların politika kararlarını etkileme gücü de artmaktadır.

Uluslararası Kamusal Katılım Derneği (IAP2, 2018) bilgi verme, danışma, katılma, işbirliği ve yetkilendirme olmak üzere katılım boyutlarını beşli bir tipolojide ele almaktadır. Katılım faaliyeti bir spektrum üzerinde bilgi vermeden yetkilendirmeye doğru yöneldikçe kararlar üzerinde yurttaşların etkilerinin de arttığı varsayılmaktadır. Katılımın yetkilendirme düzeyinde nihai karar halka bırakılır. Avrupa Konseyi (CoE, 2009) de sivil toplumun politika süreçlerine katılımını bilgilenme, danışma, diyalog ve işbirliği olmak üzere dört düzeye ayırmakta ve işbirliğini en yüksek katılım seviyesi olarak değerlendirmektedir.

Katılıma ilişkin tipolojiler katılım düzeyleri arasında hiyerarşik bir ilişki ya da önem sırası olduğu varsayımına dayanmaktadır. Yani katılımın en alt düzeyinde genellikle bilgilendirme bulunurken işbirliği ve yetkilendirme ideal olarak en üst düzeyde katılıma işaret etmektedir. Ancak belirtmek gerekir ki söz konusu hiyerarşik bakış, katılım düzeyleri arasındaki farklı ilişki biçimlerini görmemizi engellemektedir. Örneğin yurttaşların yeterli ve nitelikli düzeyde kamusal bilgiye erişemediği durumlarda etkili bir kamusal müzakere ya da işbirliği ortamının oluşturulması da zordur.

Siyasal katılma, devletin farklı yönetim kademelerindeki organlar ve kurumlar tarafından alınan siyasal ve yönetsel kararlar ile politika süreçlerini etkilemeye yönelik kamusal eylemlerden oluşmaktadır. Bu çalışmada özel olarak kent yönetimleri tarafından alınan siyasal kararlara ve kentsel politika süreçlerine katılma konusu ele alınmaktadır. Kentsel kamu politikaları, kent ölçeğindeki toplumsal sorunların çözümüne yönelik kent yönetimleri tarafından bir kamusal eylem geliştirilmesi veya eylemsizlik durumlarıdır. Kentsel kamu politikası yapımı politika sorunlarının gündeme gelmesi, tasarımı, uygulanması, izlenmesi ve değerlendirilmesi aşamalarından oluşur ve döngüsel bir süreçtir (Atkinson ve Moon, 1996: 17-19). Kentsel politikaların oluşturulması ve 
uygulanmasında belediyenin seçilmiş organları ve bürokrasisi kilit siyasal aktörlerdir. Bununla birlikte sorunun çeşidine göre kentteki siyasal parti örgütleri, dernek ve vakıflar, sermaye grupları, medya organları, sendikalar ve meslek odaları gibi farklı toplumsal ve siyasal aktörler de politika sorunlarını gündeme getirmeye, politika alternatifleri önermeye ya da politika sonuçlarını izlemeye ve değerlendirmeye çalışırlar. Tablo 1'de siyasal katılımın bilgi verme, danışma ve aktif katılım boyutları kentsel politika yapımı aşamaları ile ilişkilendirilmektedir.

Tablo 1

Kentsel Politika Yapımı ve Siyasal Katılım İlişkisi ${ }^{12}$

\begin{tabular}{|l|l|l|l|}
\hline & Bilgi Verme & Danışma & Aktif Katılım \\
\hline $\begin{array}{l}\text { Gündem } \\
\text { Belirleme }\end{array}$ & $\begin{array}{l}\text { - Belediye meclis gün- } \\
\text { demini duyurma }\end{array}$ & $\begin{array}{l}\text { - Kentin gündemindeki } \\
\text { sorunlara ilişkin kamuoyu } \\
\text { anketleri yapma }\end{array}$ & $\begin{array}{l}\text { - Yerel halkın belediye } \\
\text { meclis toplantısına gündem } \\
\text { maddesi önerebilmesi }\end{array}$ \\
\hline Tasarım & $\begin{array}{l}\text { - Belediye işlemleri ve } \\
\text { hizmetlerine ilişkin inter- } \\
\text { net gibi yollarla veri ve } \\
\text { bilgi paylaşımı }\end{array}$ & $\begin{array}{l}\text { - Belediye hizmetlerine } \\
\text { ilişkin geniş ölçekli kamu- } \\
\text { oyu araştırmaları } \\
\text { - Odak grup toplantıları ya } \\
\text { da yurttaş panelleri düzen- } \\
\text { lenmesi } \\
\text { - Sosyal medya üzerinden } \\
\text { görüş alma }\end{array}$ & $\begin{array}{l}\text { - Alternatif karar ve düzen- } \\
\text { lemeler önerme } \\
\text { - Politika sorunları veya } \\
\text { seçenleri üzerinde kamus- } \\
\text { al diyalog gerçekleştirme }\end{array}$ \\
\hline Uygulama & $\begin{array}{l}\text { - Yeni politika veya düzen- } \\
\text { lemelere ilişkin uygulama } \\
\text { rehberleri hazırlama }\end{array}$ & $\begin{array}{l}\text { - Belediye hizmetlerine } \\
\text { ilişkin talep ve şikayetleri } \\
\text { iletme }\end{array}$ & $\begin{array}{l}\text { - Sivil toplum örgütleriyle } \\
\text { ortak proje ve hizmetler } \\
\text { gerçekleştirme } \\
\text { - Kent konseyine katılarak } \\
\text { belediye meclisine proje } \\
\text { önermek }\end{array}$ \\
\hline $\begin{array}{l}\text { İleme ve } \\
\text { Değerlendirme }\end{array}$ & $\begin{array}{l}\text { - Belediye hizmetlerine } \\
\text { ilişkin faaliyet raporunu } \\
\text { paylaşma } \\
\text { ilişkin verileri paylaşma }\end{array}$ & $\begin{array}{l}\text { - Belediye hizmetleri ve } \\
\text { projelerine ilişkin memnuni- } \\
\text { yet anketine katılma }\end{array}$ & $\begin{array}{l}\text { - Sivil toplum örgütleri } \\
\text { tarafından gerçekleştirilen } \\
\text { bağımsız değerlendirmeler }\end{array}$ \\
\hline
\end{tabular}

Kamu politikalarına katılımın bilgilendirme ve danışma boyutları, yurttaşların yönetim tarafından duyulmasına, fark edilmelerine; yönetimin de yurttaşlarının seslerini duymasına imkân verir. Aktif katılım ise karar vericiler ile kamusal diyaloğa girme, sorunları müzakere etme, işbirliği geliştirme ve yurttaşı yetkilendirme yani son kararı yurttaşa bırakma gibi farklı yöntemlerden oluşmaktadır (OECD, 2001: 35-36). Aktif katılım yurttaşların kentsel sorunları gündeme getirmesini, sorunları kent yöneticileriyle müzakere etmesini, bu tür sorunların çözülmesi noktasında inisiyatif almasını ve kent yönetimleriyle birlikte karar alabilmesini, proje ve hizmetleri hayata geçirebilmesini,

1 Avrupa Konseyi Uluslararası Hükümet Dışı Organizasyonlar Konferansı (CoE, 2009) tarafından kabul edilen "Karar Verme Sürecinde Sivil Katılım İçin İyi Uygulama Kodu” ve OECD’nin (2001) "Paydaş Olarak Yurttaşlar" raporundaki politika yapma aşamaları ve katılma boyutları dikkate alınarak, verilen örnekler genişletilerek yazarlar tarafindan oluşturulmuştur.

2 OECD’nin kullandığı politika yapma süreçlerine katılım tipolojisinin dijital ortamdaki karşılıkları olarak e-bilgilendirme (e-information), e-danışma (e-consultaitions) ve e-karar verme (e-decision-making) tercih edilmektedir (bkz. European Parliament, 2016; United Nations, 2014). 
referandum ve yurttaş girişimi gibi yarı-doğrudan katılım mekanizmaları ile sorunlara ilişkin doğrudan karar vermesini sağlar. Ancak aktif katılımın etkinliği büyük ölçüde kamusal bilgiye erişim imkanının bulunmasına bağlıdır.

Katılım meselesi toplumsal ve siyasal kültür ile yakından ilişkilidir. Yaş, cinsiyet, eğitim gibi faktörlerin katılım davranışına etkisi çok sayıda araştırmaya konu olmuştur (Lamprianou, 2013: 28). Ayrıca bazı toplumlarda referandum, yurttaş vetosu ve geri çağırma gibi yetki devrine dayanan katılım pratikleri yaygın olarak kullanılırken diğerlerinde neredeyse hiç rastlanmamaktadır (Cabada, 2013). Hatta birçok ülkede siyasal katılımın temel yollarından biri olarak kabul edilen bilgi edinme hakkı anayasal veya yasal düzeyde henüz kabul edilmemiştir. Gerçek hayatta katılım çok sayıdaki aktörün farklı amaçlar doğrultusunda karar vericileri etkilemeye çalıştıkları karmaşık bir süreçtir. Katılımın etkinliği; katılacak aktörlerin etkileme gücü, katılım mekanizmalarının varlığ 1 , katılma kültürü ve karar vericilerin istekliliği gibi birçok faktöre bağlı olarak değişir. Bu nedenle çalışmada katılımın her bir boyutunun kendine özgü özelliklere sahip olduğu, birbirilerini etkilediği ve hatta zaman zaman iç içe geçtiği kabul edilmektedir.

Türkiye'de kentsel düzeyde bilgi edinmeye dayalı katılım yolları arasında yerel yönetimlerin elindeki bilgi ve belgelere erişim hakkı, çözüm masası uygulamaları ve e-belediyecilik işlemleri yaygın olarak kullanılmaktadır. Danışma ve aktif katılım boyutları bakımından yerel kamu hizmetlerine gönüllü katılım, Yerel Gündem 21 uygulamaları ve kent konseyleri gibi katılım yolları bulunmaktadır (Yıldırım ve ark. 2011: 512-514; Kocaoğlu, 2015: 191-204). Bunun yanında özellikle son dönemde çeşitli e-katılım mekanizmaları hem küresel hem yerel bağlamda öne çıkmıştır. Bilgi alma, danışma, aktif katılım, işbirliği ve yetkilendirme şeklinde çeşitli formları bulunan e-katılım yoluyla bireyler kamusal karar verme süreçlerinin farklı aşamalarına dahil olabilmektedirler. Yurttaşlar sanal ortamda oluşturulan danışma platformları, bilgisayar destekli ortak çalışmalar, çevrimiçi anketler, e-referandum, sohbet odaları, e-posta/ haberleşme grupları, çevrimiçi yayınlar, podcast'ler, arama motorları, web portalları ve bloglar gibi e-katılım araçlarını kullanarak politika yapımının farklı aşamalarına danışma ve aktif katılım gerçekleştirebilmektedir (Wirtz ve ark., 2018; Tambouris ve ark., 2007).

Bu makalede özel olarak bilgi edinme yoluyla katılıma imkân veren belediye meclis toplantılarına yerel halkın katılımı, bu katılım davranışının nedenleri ve katılımcıların sosyo-demografik profilleri incelenmektedir. $\mathrm{Bu}$ nedenle öncelikle kentsel politika yapımının önemli aktörlerinden biri olan belediye meclisinin temel işlevleri ele alınmaktadır.

\section{Kentsel Politika Yapımında Belediye Meclisinin Rolü}

Kentsel politikaların gündeme alınması ve oluşturulmasında kilit aktörler arasında yer alan belediye meclislerinin temel işlevleri arasında karar alma, denetim, temsil ve katılım öne çıkmaktadır. Belediye meclisinin işlevlerini etkin olarak yerine getirmesi büyük ölçüde uygulanan yönetişim sistemine dayanmaktadır. Dünyada yaygın olarak belediye başkanı-meclis, profesyonel yönetici-meclis ve komisyon modelleri görülmektedir (DeSantis ve Renner, 2002). Türkiye'de de uygulanan belediye başkanı ve meclisten oluşan yönetişim modelinde güçlü başkan-zayıf meclis veya zayıf başkan-güçlü meclis olmak üzere iki temel uygulama söz konusudur. 
Türkiye'de belediye sistemi, belediye başkanını meclis karşısında daha güçlü kılmaktadır. Belediye başkanının aynı zamanda karar organı olan meclisin de başkanı olması, gündem belirleme gücü ve meclis kararlarına ilişkin veto yetkisi belediye başkanlarının meclis karşısındaki gücünü pekiştirmektedir. Bu bakımdan Türkiye'de zayıf meclis-güçlü başkan modeli söz konusudur. Bu modelde iki organın prensipte birbirini dengeleyici işlevi zarar görmektedir (Oktay, 2016: 371; Erder ve İncioğlu, 2008: 274). Belediye meclisinin asimetrik güç ilişkisinde kullanabileceği yetki ve görevleri arasında stratejik planı, bütçe ve kesin hesabı kabul etmek, borçlanmaya karar vermek, belediye hizmetleriyle ilgili ücret tarifelerini belirlemek ve belediye tarafından çıkarılacak yönetmelikleri kabul etmek bulunmaktadır.

Türkiye'de belediye başkanı ile birlikte kentsel siyasetin temel aktörlerinden olan belediye meclisleri, Belediye Kanunu'nun 18. maddesinde verilen görev ve yetkiler çerçevesinde karar alır. Meclis toplantılarında alınan kararlar iki kategoriye ayrılabilir. Bunlardan birincisi yürütmenin belirlediği gündem ekseninde alınan kararlar iken diğeri meclis üyelerinin bizatihi gündeme taşıdıkları konularla ilgili alınan kararlardır (Arıkboğa ve ark., 2007: 14). Meclisler aynı zamanda kentsel sorunların gündeme taşındığı ve çözümü için politikaların üretildiği mekanlardır.

Belediye meclisinin denetim işlevi hem belediye başkanının faaliyetlerini hem de belediye yönetiminin mali (bütçe) denetimini kapsaması bakımından iki boyutludur (Arıkboğa ve ark., 2007: 16). Belediye meclisleri denetim işlevini il ve ilçe belediyeleri ile nüfusu 10.000'in üzerindeki belediyelerde kurulan denetim komisyonları, meclis üyelerine tanınan sözlü ve yazılı soru sorma yetkisi, meclis üyelerinin en az üçte birinin talebiyle açılan meclis görüşmesi, belediye faaliyet raporuna ilişkin meclis üyelerinin dörtte üçünün oyuyla alınan yetersizlik kararı ve meclis üye tam sayısının en az üçte birinin imzasıyla belediye başkanı hakkında verilen gensoru önergesi yoluyla yerine getirmektedir. Özellikle belediye meclisindeki çoğunluk ile başkanın farklı partilerden olması durumunda yukarıda değinilen yetki ve görevler ile denetim fonksiyonu daha etkili olarak kullanılabilmektedir.

Belediye meclislerinin temsil işlevi, beş yılda bir yapılan seçimler yoluyla hayata geçirilmektedir. Demokratik ülkelerde ulusal seçimlerin yanında yaygın olarak yerel yönetimlerin karar organları da seçimle belirlenir. Meclislerin oluşum sürecinde yerel seçmenlerin oylarıyla belirlenen meclis üyelikleri, doğal olarak halkın yerel karar verme sürecindeki temsilciliğidir. Her üye belirli bir toplumsal kesimin temsilcisi olup, aldıkları kararların da yurttaşların talep ve çıkarlarını savunmak adına alındığı kabul edilir (Arıkboğa ve ark., 2007: 15). Belediyelerin temsil ile birlikte değerlendirilmesi gereken diğer bir işlevi ise katılımdır. Belediye meclisine katılım, meclis toplantılarının halka açık olması ve genellikle oy hakkı olmaksızın toplantıların izlenebilmesini kapsamaktadır. Aktif katılım açısında bakıldığında meclis gündeminin seçmenler tarafindan belirlenebilmesi, yerel seçmenlerin meclise karar taslağı sunabilmesi, meclis kararlarının referanduma götürülebilmesi ve meclis üyeleri hakkında geri çağırma mekanizmasının kullanılabilmesi gibi doğrudan ve yarı doğrudan katılım mekanizmaları da bulunmaktadır (Sobacı ve Köseoğlu, 2016).

Türkiye'de belediye meclislerinde yasal olarak iki tür katılım yolu öne çıkmaktadır. İlk olarak mahalle muhtarları, kamu meslek örgütü temsilcileri, üniversiteler, sendikalar ve 
STK temsilcileri oy hakkı olmaksızın kendi görev ve faaliyet alanlarına giren konuların görüşüldüğü ihtisas komisyonu toplantılarına katılma ve görüş bildirebilme hakkına sahiptir. İkinci olarak 5393 sayılı Kanuna göre ${ }^{3}$ meclis toplantıları halka açıktır. Böylece yurttaşların meclis toplantılarına oy hakkı olmaksızın katılma olanakları bulunmaktadır.

\section{Belediye Meclis Toplantılarına Yurttaş Katılımına İlişkin Bir Araştırma}

\section{Literatür İncelemesi}

Türkiye'de yerel demokrasi ve belediyelerde siyasal katılımla ilgili geniş bir literatür bulunmaktadır. Belediye meclisleri, meclis üyelerinin sosyo-demografik özellikleri, belediyelerde kadın temsili, belediye meclislerinde temsil adaletsizliği gibi konular çok sayıda teorik ve ampirik çalışmaya konu edilmiştir.

Bu çalışmalar içerisinde belediye meclislerinin siyasi temsil işlevi üzerine gerçekleştirilen ampirik araştırmalar öne çıkmaktadır. Bu kapsamdaki en eski çalışmalardan birisi Çitçi (1989) tarafından 1984 yerel seçimlerinin ardından belediye meclis üyeleri ve başkanlarının profillerinin belirlendiği araştırmadır. Son yıllarda farklı iller özelinde büyükşehir, il ve/ veya ilçe belediye meclislerinin temsil ediciliği, meclis üyelerinin demografik profili ve meclislerde kadın temsilini inceleyen çok sayıda araştırma dikkati çekmektedir (bkz. Arıkboğa ve ark., 2007; Bulut ve Tanıyıcı, 2008; Çelik ve Uluç, 2009; Türeli ve Çağlar, 2010; Aksu ve Kurtuluş, 2011; Oktay, 2013; Yıldırım ve ark., 2011 ve 2015; Uyan Semerci, 2015). Temsil işleviyle ilgili bazı çalışmalar 5747 sayılı ve 6360 sayılı kanunlarla gerçekleştirilen ölçek reformları neticesinde büyükşehir belediye meclislerinde derinleşen temsilde adalet sorununa odaklanmaktadır (Arıkboğa, 2009 ve 2014; Güneş, 2017).

Karar verme işlevi bağlamında belediye meclisinin siyasi parti örgütleriyle (Alkan ve Çiftçioğlu, 2007) ve belediyenin diğer organlarıyla ilişskileri (Azaklı ve Özgür, 2005); meclis üyelerinin karar verirken dikkate aldıkları faktörler (Sezik, 2017) ve meclisin karar vermesinde kent konseylerinin rolü (Lamba ve Kerman, 2016) incelenmiştir. Belediye meclisleri özelinde yerel yönetimlerde halkın politika yapımına katılımı, halkın yerel demokrasi ve katılım algısı ile yerel sorunlara gösterilen ilginin incelendiği çalışmalar da söz konusudur (bkz. Arıkboğa, 2010; Uçar ve Negiz, 2016; Zeren ve Özmen, 2010). Literatür incelemesi sonucunda belediye meclis toplantılarına yurttaşların katılımı konusunu doğrudan ele alan bir çalışmaya rastlanmamıştır.

Meclis toplantılarını izlemek Milbrath ve Goel'in (1977) “izleyiciler” (spectators) olarak adlandırdığı siyasal katılma türüdür. İzleyiciler siyasal tartışmalara katılan, siyasetle ilgili bilgi edinmeye devam eden, siyasal olayları dışarıdan izleyen kimselerdir. Belediye meclisinin kentsel politikaların gündeme getirilmesi ve oluşturulması sürecindeki rolü dikkate alındığında yurttaşların meclis toplantılarına ilgi göstermesi, meclis gündemini takip etmesi ve alınacak kararlar hakkında bilgi sahibi olması diğer siyasal katılım davranışlarını da etkileyeceğinden araştırmaya değer bulunmuştur.

\section{Araştırma Problemi}

Literatür incelendiğinde belediye meclislerinin farklı boyutlarıyla kamu yönetimi, siyaset bilimi, yerel yönetimler ve kentleşme disiplinleri altında çalışıldığı anlaşılmaktadır.

31580 sayılı eski Belediye Kanunu'nda “belediye müzakeresinin açık” olduğu ifade edilmiştir. 
$\mathrm{Bu}$ çalışmalarda belediye meclis üyelerinin demografik özellikleri yoğun bir şekilde araştırılırken, meclis toplantılarına dışarıdan katılan yurttaşlar daha önce araştırma konusu yapılmamıştır.

Bu makale, önceki çalışmalardan farklı olarak, kentsel politikalarla ilgili bilgi edinmeye dayanan siyasal katılım eylemi bağlamında meclis üyeleri, medya mensupları ve belediye bürokratları haricinde meclis toplantılarına yerel halktan ilgi gösterenlerin demografik profilleri, siyasi eğilimleri ve katılım amaçlarını araştırmayı amaçlamaktadır. Farklı kentleri ve belediyeleri kapsayacak şekilde ileride yapılacak olan diğer araştırmalarla birlikte belediye meclisleri bağlamında bilgilenmeye dayanan siyasal katılım dinamiklerine ilişkin daha kapsamlı bulgulara ulaşma imkânı olacağı düşünülmektedir.

Seçmenlerin yerel seçimlere katılarak belediye başkanı ve meclis için oy vermesi siyasal katılımın temel bir unsurudur. Gelişmiş ülkelerle karşılaştırıldığında Türkiye'de yerel seçimlere katılım oranları oldukça yüksek seyretmektedir. Belediye meclisleri açısından seçimlere katılma oran1 2009 yerel seçimlerinde \%85,19, 2014 yerel seçimlerinde $\% 89,19$ ve 2019 'da ise \%84,67 olarak gerçekleşmiştir (www.ysk.gov.tr). Bununla birlikte, yerel seçmenlerin seçimlerde oy verme dişında, herhangi bir zorunluluk bulunmamasına rağmen, yerel meclislere ilgi göstermesi, oy hakkı olmadığ 1 halde toplantılara katılması ve meclis gündemini takip etmesi, yurttaşların yerel siyasete ilgisi ve yerel demokrasinin düzeyiyle ilgili bir gösterge oluşturması bakımından önemlidir. Bu nedenle katılımcılara yerel demokrasi algıları ve siyasal katılım düzeylerine ilişkin sorular da yöneltilmiştir.

Demokrasilerde yurttaşların siyasal olayları gözlemlemesi ve katılımı zorunlu gören gerçekçi bir algıya sahip olması önemli görülür. Yurttaşların siyasal eğitimi ve ileriki dönemlerde muhtemel aktif katılım davranışlarına yönelmesi açısından bilgilenmeye dayanan katılım eylemleri oldukça önemlidir (Hague ve ark., 2016:217). Meclis toplantıları gibi kent gündeminin görüşüldüğü, kent halkını etkileyen temel politika kararlarının alındığı mekanlarda tartışmaları yerinde izlemek ve siyasal süreçler hakkında bilgilenmek de bizatihi bu bağlamda bir siyasal katılım biçimi olarak değerlendirilmektedir. $\mathrm{Bu}$ toplantılara kimlerin hangi amaçla katıldığını belirlemenin, profillerini ortaya koymanın siyasal katılımın doğasını anlamak açısından değerli olduğu düşünülmektedir.

\section{Araştırma Soruları}

Makalenin temel amacı, belediyeler açısından siyasal katılımın geleneksel bir yolu olan belediye meclis toplantılarına ilgi göstererek katılan yurttaşların demografik özellikleri, katılım nedenleri, yerel demokrasi algıları ve belediye faaliyetlerine katılım düzeylerine ilişkin görüşlerini ortaya koymaktır. Bu amaç doğrultusunda iki temel araştırma sorusu belirlenmiştir:

1. Belediye meclis toplantılarına katılan yurttaşların demografik özellikleri, katılım sıklığı ve nedenleri nelerdir?

2. Belediye meclis toplantılarını yerinde izleyen yurttaşların yerel demokrasi algıları ve siyasal katılımın farklı boyutlarına ilişkin görüşleri nasıldır?

\section{Araştırmanın Yöntemi ve Sınırlılıkları}

Yukarıda yer verilen araştırma sorularına yanıtlar aramak amacıyla katılımcı gözlem ve 
anket yöntemleri kullanılmıştır. Seçilen belediyelerde araştırmacılar meclis toplantılarına doğrudan katılmış ve cevaplamak isteyenlerin dahil olduğu yüz yüze anket uygulaması gerçekleştirmiştir.

$\mathrm{Bu}$ kapsamda ilk olarak araştırmada kullanılacak olan anket tasarlanmıştır. Bu konuda hazır bir ölçek bulunmadığından anket büyük ölçüde araştırmacılar tarafından tasarlanmıştır. Anket güvenilirliğini artırmak için soruların tasarım sürecinde uzman görüşüne başvurulmuş ve bir ilçe belediyesinde üç ay boyunca meclis toplantıları izlenmek suretiyle pilot uygulama gerçekleştirilmiştir. Uzman görüşleri ve pilot uygulama neticesinde ölçekte anlaşılmayan sorular gözden geçirilmiş, demografik bulgulara ilişkin sorularda düzeltme ve eklemeler yapılmış, belediye meclisi algısı ve katılıma ilişkin sorular üçlü Likert ölçeğine dönüştürülmüştür. Bu süreçlerin sonunda ankete son hali verilerek uygulamaya geçilmiştir.

Son yıllarda yapılan yasal değişiklikler neticesinde Türkiye'de büyükşehirlerin yönetiminde büyükşehir belediyesi ve büyükşehir ilçe belediyesinden oluşan metropoliten kent yönetimi modeline geçilmiştir. Bu nedenle, anakent belediyesi yanında belirli sayıda büyükşehir ilçe belediyesinin örneklem içine alınması ihtiyacı ortaya çıkmıştır. Hangi büyükşehir ilçe belediyelerinin araştırma kapsamına dahil edileceğini belirlemede ulaşım maliyetleri, nüfus ve erişilebilirlik kısıtları dikkate alınmıştır.

Meclislere dışarıdan katılanları tespit etmek ve katılımcılara hazırlanan anketi uygulamak için belediye meclis toplantılarına araştırmacılar tarafından doğrudan katılım gerçekleştirilmesi gerektiğinden öncelikle şehir merkezinde bulunan ve ulaşımı kolay olan belediyeler tercih edilmiştir. Belediye nüfusunun fazla olması, meclisin büyüklüğünü doğrudan etkilediğinden ilçe nüfusları da bir kısıt olarak değerlendirilmiştir. Bunun yanında, ilgili ilçe belediyesinden meclis toplantılarına katılanlara anket uygulanması için gerekli izinlerin alınmış olması, yani erişim sorunu bulunmamasına özen gösterilmiştir. Bu kısıtlara dayalı olarak araştırmaya Sakarya ilinde Adapazarı, Arifiye, Erenler ve Serdivan büyükşehir ilçe belediye meclisleri ile Sakarya büyükşehir belediye meclisi dahil edilmiştir.

Araştırma kapsamındaki belediye meclislerinin Mart-Kasım 2018 tarihleri arasında 9 ay boyunca gerçekleştirdikleri toplantılar izlenmiş ve kolayda örnekleme tekniğine göre, o anda toplantıya dışarıdan katılan kişilerden istekli olanlara anket uygulanmıştır. Araştırmacılar, 9 aylık süre boyunca söz konusu belediyelerin toplamda 40 meclis toplantısına doğrudan katılım sağlamıştır. Genel bir gözlem olarak, meclisin resmi üyeleri dışında yurttaşların belediye meclisine yönelik katılımının düşük olduğu söylenebilir.

Katılım sağlanan meclislerin yaz döneminde bir aylık tatil uygulaması ve bazı toplantılarda ise meclis dışından hiç katılıma rastlanılmaması nedeniyle anket uygulanamamıştır. Bunun dışındaki meclis toplantılarında toplam 50 kişi ile görüşülerek anketi doldurması sağlanmıştır. Anketler toplandıktan sonra SPSS 22 programı kullanılarak veri tabanı oluşturulmuş ve veriler üzerinde betimsel istatistiki analizler uygulanmıştır. Betimsel istatistiki analizler için gözlem büyüklüğü yeterli kabul edilmektedir (bkz. Altunışık ve ark., 2012: 137).

\section{Araştırma Bulguları}

Araştırma bulguları, katılımcılara ilişkin demografik özellikler ve katılıma ilişkin bulgular olmak üzere iki başlık altında değerlendirilmektedir. 


\section{Demografik Bulgular}

Araştırmaya katılanlara ilişkin temel demografik bulgular Tablo 2'de gösterilmektedir. Katılımcıların yaş dağılımına bakıldığında 18-25 arası genç grubun diğer yaş grupları içindeki oranının düşük olduğu görülmektedir (\%12). Katılımcıların büyük çoğunluğu (\%48) 46 yaş üstündedir. Toplumsal olarak orta yaş grubunun belediye meclis toplantılarına ilgisinin diğer yaş gruplarına göre yüksek olduğu anlaşılmaktadır.

Katılımcıların eğitim durumu incelendiğinde, üniversite mezunu (önlisans, lisans ve lisansüstü) olanlar \%58 $(\mathrm{n}=29)$ ile en geniş grubu oluşturmaktadır. Gelir düzeyi sorusuna cevap verenlerin yaklaşı $\% 45$ 'i aylık gelirlerinin $2.500 \mathrm{TL}$ ve altında olduğunu belirtirken, bu grubun içinden de \%8,2'sinin geliri 1.500TL'nin altındadır.

Ayrıca katılımcıların \%86'sı erkek iken sadece \%14'ü kadındır. Meclis toplantılarına gençlerin ve kadınların ilgisi oldukça düşük gözükmektedir. Bu veriler Türkiye' de gençler ve kadınların yerel temsilde karşılaştığı sorunlara odaklanan araştırma bulgularıyla uyumlu gözükmektedir (bkz. Arıkboğa ve ark., 2007: 72-76; Çelik ve Uluç, 2009: 220; Oktay, 2013: 143; Erdoğan, 2015: 80-85; Uçar ve Negiz, 2016).

Tablo 2

Katılımcıların Demografik Bulguları

\begin{tabular}{|c|c|c|c|}
\hline Özellik & Kategori & Frekans & Yüzde (\%) \\
\hline \multirow{3}{*}{ Cinsiyet } & Erkek & 43 & 86 \\
\hline & Kadın & 7 & 14 \\
\hline & Toplam & 50 & 100 \\
\hline \multirow{6}{*}{ Yaş Grupları } & $18-25$ yaş & 6 & 12 \\
\hline & $26-35$ yaş & 12 & 24 \\
\hline & $36-45$ yaş & 8 & 16 \\
\hline & $46-65$ yaş & 23 & 46 \\
\hline & $66+$ yaş & 1 & 2 \\
\hline & Toplam & 50 & 100 \\
\hline \multirow{7}{*}{ Eğitim Durumu } & Okuma yazma biliyorum & 1 & 2 \\
\hline & İlköğretim & 9 & 18 \\
\hline & Lise & 11 & 22 \\
\hline & Önlisans & 7 & 14 \\
\hline & Lisans & 18 & 36 \\
\hline & Lisansüstü & 4 & 8 \\
\hline & Toplam & 50 & 100 \\
\hline \multirow{7}{*}{ Gelir Düzeyi } & 1.500 ve alt1 & 4 & 8,2 \\
\hline & $1.501-2500$ & 18 & 36,7 \\
\hline & $2.501-3500$ & 10 & 20,4 \\
\hline & $3.501-4500$ & 8 & 16,3 \\
\hline & $4.501-5500$ & 5 & 10,2 \\
\hline & 5.501 ve üstü & 4 & 8,2 \\
\hline & Toplam & 49 & 100 \\
\hline
\end{tabular}

Araştırmaya katılanların meslekleri açısından bakıldığında, emekli ( $\mathrm{n}=8)$, serbest meslek $(n=6)$, gazeteci $(n=3)$ ve mali müşavir $(n=3)$ cevapları öne çıkmaktadır. Sadece 1 kez verilen yanıtlar "diğer" kategorisi altında toplanmıştır. Bu kategoride mimar, esnaf, biyolog, harita 
mühendisi, muhtar, işçi ve antrenör gibi meslekler belirtilmiştir. Bu soruya verilen yanıtlar açık uçlu olarak alındığından meslekler arasında iç içe geçmeler söz konusudur. Örneğin mali müşavirlik ve antrenörlük gibi meslekler de serbest meslek içinde değerlendirildiğinde katılımcıların büyük kısmının serbest meslek mensubu olduğu söylenebilir.

Tablo 3

Katılımciların Meslekleri

\begin{tabular}{|l|c|c|}
\hline Meslek & Frekans & Yüzde (\%) \\
\hline Emekli & 8 & 17,4 \\
\hline Serbest meslek & 6 & 13 \\
\hline Gazeteci & 3 & 6,5 \\
\hline Mali müşavir & 3 & 6,5 \\
\hline Ev hanımı & 2 & 4,3 \\
\hline Ö̆ğrenci & 2 & 4,3 \\
\hline Tekniker & 2 & 4,3 \\
\hline Ticaret & 2 & 4,3 \\
\hline Yönetici & 2 & 4,3 \\
\hline Diğer & 16 & 35,1 \\
\hline Toplam & 46 & 100 \\
\hline
\end{tabular}

Tablo 4 incelendiğinde katılımcıların büyük kısmının Sakarya'da uzun süredir yaşayan, yerleşik olarak nitelenebilecek kişiler olduğu görülmektedir. Ankete cevap verenlerin \%14’ü $(n=7)$ 2-10 y1l arası; \%12'si (n=6) 11-20 y1l arası ve \%70'i (n=35) 21 y1ldan fazla süredir Sakarya'da yaşadığını beyan etmiştir. 1 yılın altında yaşayanların oranı ise sadece $\% 4$ 'tür.

Tablo 4

Sakarya'da Yaşadı̆̆ı Süre

\begin{tabular}{|l|c|c|}
\hline Süre & Frekans & Yüzde (\%) \\
\hline 1 y1ldan az & 2 & 4 \\
\hline 2-5 y1l aras1 & 2 & 4 \\
\hline 6-10 y1l aras1 & 5 & 10 \\
\hline $11-15$ y1l aras1 & 2 & 4 \\
\hline $16-20$ y1l aras1 & 4 & 8 \\
\hline 21 y1ldan fazla & 35 & 70 \\
\hline Toplam & 50 & 100 \\
\hline
\end{tabular}

\section{Siyasete Ilgi, Parti Üyeliği ve Oy Verme}

Bireylerin demokratik katılım davranışının arkasındaki temel motivasyon unsurlarından birisi siyasal ilgi düzeyidir. Katılımcıların ulusal ve yerel siyasete ilgisini ölçmek amaciyla üç soru sorulmuştur. Sorulara verilen cevaplar analiz edildiğinde belediye meclis toplantılarına katılanların yerel ve ulusal siyasete, toplumsal sorunlara ve siyasal gündeme ilgisinin yüksek olduğu anlaşılmaktadır. Anketi yanıtlayanların 93,9'u (n=46) yerel gazeteleri düzenli olarak takip ettiğini belirtirken; \%92'si $(n=46)$ yerel siyaseti ve \%89,8'i (n=44) ise ulusal siyaseti yakından takip ettiğini ifade etmiştir (bkz. Tablo 5). Bu veriler birlikte değerlendirildiğinde, meclis toplantılarına katılanların yerel siyasete ve kentsel sorunlarla yakından ilgisi olan, siyasal bilinci yüksek bireyler olduğu söylenebilir. 
Tablo 5

Katılımciların Siyasete İlgisi

\begin{tabular}{|l|c|c|c|c|c|c|}
\hline \multirow{2}{*}{$\begin{array}{l}\text { İlgi Soruları } \\
\text { Katılıyorum }\end{array}$} & \multicolumn{2}{c|}{$\begin{array}{c}\text { Kısmen } \\
\text { Katılıorum }\end{array}$} & \multicolumn{2}{c|}{ Katılmıorum } \\
\cline { 2 - 8 } & Frekans & Yüzde & Frekans & Yüzde & Frekans & Yüzde \\
\hline Yerel siyaseti yakından takip ederim. & 46 & 92 & 2 & 4 & 2 & 4 \\
\hline $\begin{array}{l}\text { Ulusal siyasal olayları günlük olarak takip } \\
\text { ederim. }\end{array}$ & 44 & 89,8 & 1 & 2 & 4 & 8,2 \\
\hline Yerel gazeteleri düzenli olarak takip ederim. & 46 & 93,9 & 0 & 0 & 3 & 6,1 \\
\hline
\end{tabular}

Siyasi parti üyeliği ve seçimlere katılarak oy vermek siyasal katılımın yaygın örnekleri arasındadır. Bu bağlamda katılımcılara en son yerel seçimlere (30 Mart 2014 seçimleri kastedilmiştir) katılıp katılmadıkları ve katılmaları durumunda belediye meclisi için oy verdikleri parti sorulmuştur ${ }^{4}$. Buna göre, katılımcıların yaklaşık \%86'sı seçimlere katılarak bir partiye oy verdiğini belirtirken, \%14'ü ise son seçimlere katılmadığını ifade etmiştir. Oy verenlerin \%44,9'u AK Partiye, \%24,5'i MHP'ye ve \%16,3'ü ise CHP'ye oy verdiğini beyan etmiştir (bkz. Tablo 6). Katılımcıların \%67,7'si (n=32) bir siyasi parti üyesi olduğunu belirtmiştir. Oy verilen partilerde olduğu gibi üye olunan partiler arasında da AK Parti ve MHP ön sirada yer almaktadır.

Tablo 6

Katılımcıların Son Seçimlerde Oy Verdiği Partiler ve Parti Üyeliğ $i$

\begin{tabular}{|l|c|c|c|}
\hline Soru & Siyasi Parti & Frekans & Yüzde (\%) \\
\hline \multirow{4}{*}{$\begin{array}{l}\text { En son seçimlerde oy } \\
\text { verilen parti }\end{array}$} & Oy vermedim & 7 & 14,3 \\
\cline { 2 - 4 } & AK Parti & 22 & 44,9 \\
\cline { 2 - 4 } & MHP & 12 & 24,5 \\
\cline { 2 - 4 } & CHP & 8 & 16,3 \\
\hline \multirow{5}{*}{ Siyasi parti üyeliği } & Toplam & 49 & 100 \\
\cline { 2 - 4 } & Yok & 16 & 33,3 \\
\cline { 2 - 4 } & AK Parti & 10 & 20,8 \\
\cline { 2 - 4 } & MHP & 6 & 20,8 \\
\cline { 2 - 4 } & CHP & 5 & 12,5 \\
\cline { 2 - 4 } & Parti adı belirtmeyen & 1 & 10,4 \\
\cline { 2 - 4 } & İyi Parti & 48 & 2,1 \\
\hline
\end{tabular}

Tablo 6 incelendiğinde belediye meclis toplantılarına ilgi göstererek katılanların büyük kısmının en son seçimlere katılarak oy verdiği ve parti üyesi olduğu anlaşılmaktadır. Bu nedenle, anketi cevaplandıranlarda oy verme ve siyasi parti üyeliği şeklindeki siyasal katılım davranışı yüksektir.

4 Bu çalışmada saha araştırması Mart-Kasım 2018 tarihleri arasında yürütüldüğünden ziyaret edilen belediye meclislerinin parti dağılımları 30 Mart 2014 mahalli idareler seçimlerinin neticesinde oluşmuştur. Buna göre, araștırmanın yapıldığı ilçe belediye meclislerinden Adapazarı'nda \%52,8; Erenler'de \%55,9; Serdivan'da $\% 53,3$ ve Arifye'de \%61,9 oy çokluğu ile AK Parti birinci partidir. Büyükșehir belediye meclisinde ise AK Parti \%54,4; MHP 29,2, CHP \%8,5, SP \%4,9 ve BBP \%1,1 ile temsil edilmektedir (bkz. www.ysk.gov.tr). 


\section{Belediye Meclisine Katılım Sıklı̆̆ı ve Nedenleri}

$\mathrm{Bu}$ makalenin temel araştırma sorularından birisi olması nedeniyle belediye meclis toplantılarına dışarıdan ilgi duyup katılanların katılma sıklığı ölçülmüş ve katılım nedenlerine ilişkin açık uçlu bir soruyla katılımcılardan veri toplanmıştır. Buna göre, anketi yanıtlayanların \%56'sı sıklıkla (Y1lda 5-6 kez ve her ay düzenli olarak) meclis toplantılarına katıldıklarını ifade etmiştir. Ankete cevap verenlerin \%14'ü az (yılda 3-4 kez) ve \%30’u çok az (yılda 1-2 kez) belediye meclis toplantılarına katılmaktadır (bkz. Tablo 7).

Tablo 7

Meclis Toplantılarına Katılım Siklı̆̆

\begin{tabular}{|l|c|c|}
\hline Katılım Sıklı̆̆ & Frekans & Yüzde (\%) \\
\hline Her ay düzenli olarak & 12 & 24 \\
\hline Yılda 5-6 kez & 16 & 32 \\
\hline Y1lda 3-4 kez & 7 & 14 \\
\hline Y1lda 1-2 kez & 15 & 30 \\
\hline Toplam & 50 & 100 \\
\hline
\end{tabular}

Resmi görevi olmadığı halde belediye meclis toplantılarına katılan yurttaşların, katılım nedenlerine ilişkin açık uçlu soruya verilen cevaplar kodlanarak gruplandırılmış ve Tablo 8'de gösterilen sıklık değerlerine ulaşılmıştır. Buna göre iki temel kategori öne çıkmaktadır. Katılımcıların büyük kısmı ya gündemi, kararları ve meclisi takip etmek $(n=16, \% 33,4)$ ya da bilgi edinmek ve toplantıları dinlemek $(n=16, \% 33,4)$ için katıldıklarını ifade etmektedir.

Tablo 8

Meclis Toplantılarına Katılım Nedenleri

\begin{tabular}{|c|c|c|}
\hline Katılım Nedeni & Frekans & Yüzde (\%) \\
\hline Gündemi takip etmek & 12 & 25 \\
\hline Bilgilenmek & 10 & 20,8 \\
\hline Dinlemek & 3 & 6,3 \\
\hline Sorunlara çözüm bulunduğunu görmek & 3 & 6,3 \\
\hline Kararları takip etmek & 2 & 4,2 \\
\hline Meclisi/Meclis üyeleri takip etmek & 2 & 4,2 \\
\hline Görev gereği & 2 & 4,2 \\
\hline Sorunları gündeme getirmek için & 2 & 4,2 \\
\hline İmar ile ilgili & 2 & 4,2 \\
\hline Siyasal patiyi temsilen & 2 & 4,2 \\
\hline Diğer nedenler & 8 & 16,7 \\
\hline Toplam & 48 & 100 \\
\hline
\end{tabular}

Tablo 8'de yer verilen "diğer nedenler" arasında "siyasetle uğraşıyor olmak", "hatıraları tazelemek", "eski belediye meclis üyesi olmak", "tesadüfen”, "merak etmek”, "muhtarlar derneğini temsil etmek", "tecrübe kazanmak" ve "haber yapmak" bulunmaktadır. 


\section{Yerel Demokrasi Algısı}

Katılımcıların belediye meclisine yönelik görüşlerinin, onların yerel demokrasi konusundaki yaklaşımları üzerinde belirleyici olduğu varsayılmaktadır. Bu kapsamda, anketi cevaplandıranlara belediye meclisiyle ilgili altı ifade sorulmuştur. Ayrıca belediye başkanının seçimle gelmesine yönelik görüşlerini almak için de bir soru eklenmiştir. Tablo 9 incelendiğinde ankete cevap verenlerin \%83,3’ü $(n=40)$ meclis toplantılarına katılmayı hemşehrilik görevi olarak değerlendirirken, \%87,8'i (n=43) toplantılara katılımın şehre olan bağlılığını artırdığını, yani hemşehrilik bilincini güçlendirdiğini düşünmektedir. Bununla birlikte, katılımcıların büyük kısmı $(\% 58,9)$ meclis toplantılarına şehir sakinlerinin yeterince ilgi göstermediğinden yakınmaktadır. Benzer ampirik araştırmalarda da belediye meclis toplantılarına katılımın yetersiz olduğu görülmektedir (Arıkboğa ve ark., 2007: 76; Bulut ve Tanıyıc1, 2008: 185; Zeren ve Özmen, 2010: 170).

Tablo 9

Belediye Meclisi ve Yerel Demokrasi Algisı

\begin{tabular}{|l|c|c|c|c|c|c|}
\hline \multirow{2}{*}{ Yerel Demokrasiye İlişkin İfadeler } & \multicolumn{2}{|c|}{ Katılıorum } & \multicolumn{2}{c|}{$\begin{array}{c}\text { Kısmen } \\
\text { Katılıorum }\end{array}$} & \multicolumn{2}{c|}{ Katılmıorum } \\
\cline { 2 - 7 } & Frekans & Yüzde & Frekans & Yüzde & Frekans & Yüzde \\
\hline $\begin{array}{l}\text { Meclis toplantılarına katılmak hemşehrilik } \\
\text { görevidir. }\end{array}$ & 40 & 83,3 & 1 & 2,1 & 7 & 14,6 \\
\hline $\begin{array}{l}\text { Meclis toplantılarına katılmak şehre olan } \\
\text { bağlılığımı artırır. }\end{array}$ & 43 & 87,8 & 2 & 4,1 & 4 & 8,2 \\
\hline $\begin{array}{l}\text { Meclis toplantılarına şehir sakinleri yeterince } \\
\text { ilgi göstermektedir. }\end{array}$ & 19 & 40,4 & 5 & 10,6 & 23 & 48,9 \\
\hline $\begin{array}{l}\text { Meclisler demokrasi kültürünün } \\
\text { yerleşmesinde önemlidir. }\end{array}$ & 45 & 93,8 & 0 & 0 & 3 & 6,3 \\
\hline $\begin{array}{l}\text { Meclis üyelerinin atamayla belirlenmesini } \\
\text { desteklerim. }\end{array}$ & 11 & 22,9 & 4 & 8,3 & 33 & 68,8 \\
\hline $\begin{array}{l}\text { Belediye başkanının atamayla belirlenmesini } \\
\text { desteklerim. }\end{array}$ & 8 & 17 & 0 & 0 & 39 & 83 \\
\hline
\end{tabular}

Belediye meclislerinin seçimle belirlenmesi, yerel demokrasinin temel unsurlarından birisidir. Avrupa Yerel Yönetimler Özerklik Şartı'nın 3. maddesine göre yerel yönetimler "eşit ve genel oya dayanan gizli seçim sistemine göre serbestçe seçilmiş üyelerden oluşan ve kendilerine karşı sorumlu yürütme organlarına sahip olabilen meclisler ... tarafından kullanı[lır]". Türkiye'de belediye meclisleri ile birlikte yürütme organı olan belediye başkanları da doğrudan seçmenler tarafindan genel ve eşit oya dayalı olarak gizli yapılan seçimler neticesinde belirlenmektedir. Bu nedenle katılımcıların yerel demokrasi algısını ölçmek amacıyla hem belediye meclisi hem de belediye başkanlığının atamayla belirlenmesi hakkında ne düşündükleri sorulmuştur. Buna göre, katılımcıların \%83'ü $(n=47)$ belediye başkanının ve yaklaşık \%70'i $(n=33)$ ise meclis üyelerinin atamayla belirlenmesi fikrini desteklememektedir. $\mathrm{Bu}$ veriye ek olarak, belediye meclislerinin demokrasi kültürünün yerleşmesindeki yeri katılımcıların yaklaşı \% \%94’ü tarafından önemli görülmektedir (bkz. Tablo 9). 


\section{Meclis Üyeleriyle İlgili Görüşler}

Meclis toplantılarına dışarıdan katılan yurttaşların belediye meclis üyeleriyle ilişkileri konusunda dört ifadeye katılım düzeyleri üçlü Likert ölçeği kullanılarak ölçülmüştür. Tablo 10 incelendiğinde, cevap verenlerin \%78'i meclis üyelerine rahatlıkla ulaşabileceğini; $\% 65,3$ 'ü meclis üyelerinin halkın sorunlarıyla yakından ilgilendiğini ve $\% 58,3$ 'ü ise talep ve şikayetlerini çözebileceklerini düşünmektedir. Ayrıca yanıt verenlerin \%63,3'ü meclis üyeleri ile sıkça görüştüğünü belirtmiştir.

Tablo 10

Meclis Üyeleri Hakkındaki Ifadelere Katılma Düzeyi

\begin{tabular}{|l|c|c|c|c|c|c|}
\hline \multirow{2}{*}{ Meclis Üyeleriyle İlgili İfadeler } & \multicolumn{2}{|c|}{ Katılıorum } & \multicolumn{2}{c|}{$\begin{array}{c}\text { Kısmen } \\
\text { Katılıyorum }\end{array}$} & \multicolumn{2}{c|}{ Katılmıyorum } \\
\cline { 2 - 7 } & Frekans & Yüzde & Frekans & Yüzde & Frekans & Yüzde \\
\hline Meclis üyelerine rahatlıkla ulaşabilirim. & 39 & 78 & 4 & 8 & 7 & 14 \\
\hline $\begin{array}{l}\text { Meclis üyeleri halkın sorunlarıyla } \\
\text { yakından ilgilenir. }\end{array}$ & 32 & 65,3 & 7 & 14,3 & 10 & 20,4 \\
\hline Meclis üyeleri ile sıkça görüşürüm. & 31 & 63,3 & 5 & 10,2 & 13 & 26,5 \\
\hline Meclis üyeleri talep ve şikayetlerimi çözer. & 28 & 58,3 & 8 & 16,7 & 12 & 25 \\
\hline
\end{tabular}

Bulgular, katılımcıların meclis üyelerine kolayca erişebildiğini ve meclis üyelerinin toplumsal sorunlara ilgisinin yüksek olduğunu, ancak yurttaşların taleplerini karşılama ve şikayetlerini çözme noktasında nispeten yetersiz kaldıklarını göstermektedir. Meclislerin kolektif organlar olması ve belediye hizmetlerinin yürütülmesiyle ilgili yetkilerinin sınırlı olması gibi yapısal nedenlerle katılımcıların talep ve şikayetlerini çözmede meclis üyelerine duydukları güvenin çok yüksek olmadığı düşünülmektedir. Nitekim, benzer araştırmalarda yerel karar alma süreçlerine katılım için yurttaşlar tarafindan en çok başvurulan mercii belediye başkanı ve meclis üyeleri olarak belirtilmesine rağmen, meclis üyelerinin karar mekanizmalarında sadece sınırlı bir işleve sahip oldukları vurgulanmaktadır (Arıkboğa ve ark., 2007: 88, Alkan ve Çiftçioğlu, 2007; Bulut ve Tanıyıc1, 2008; Erder ve İncioğlu, 2008; Uyan Semerci, 2015).

\section{Belediyelerde Katılım Yollarına İlişkin Görüşler}

Daha önce de ifade edildiği gibi belediyelerde katılım bilgilendirme, danışma ve (müzakereci, işbirliği ve ortaklığa dayalı katılımı da kapsayacak şekilde) aktif katılım olmak üzere üç boyuta ayrılabilir. Katılımın farklı boyutları hakkında meclis toplantılarına dahil olanların görüşlerini ölçmek amacıyla bir dizi soru hazırlanmıştır.

Bilgi edinme boyutu bağlamında katılımcıların belediyenin stratejik planı, faaliyet raporları, gündemi, kararları, vizyonu, görev ve yetkileri hakkında ne kadar bilgisi olduğu araştırılmıştır. Bu kapsamda sorulan sorulara katılımcıların verdiği cevaplar Tablo 11'de gösterilmektedir. Belediyelerin vizyon ve misyonu, mali yapısı, gelir ve harcamaları, orta ve uzun vadeli hedefleri ve bu hedeflere ulaşma düzeyiyle ilgili temel bilgiler stratejik plan, faaliyet raporu ve vizyon ifadesinde açıklanır. Katılımcıların \%71,4'ü belediyenin vizyonu, $\% 63,3$ 'ü faaliyet raporları ve $\% 53,1$ ' $\mathrm{i}$ ise stratejik planı hakkında bilgi sahibi olduğunu ifade etmiştir. Stratejik planların kapsamlı olması ve meclis gündemine genelde kabul edilme döneminde, yani 4-5 yılda bir gelmesi nedeniyle bilinirliği de düşük kalmaktadır. 
Katılımcıların \%68'i $(n=34)$ belediye meclis gündemini ve \%75'i $(n=36)$ belediye kararlarını düzenli olarak takip ettiklerini beyan etmiştir. Bu oranlar, Tablo 7 ve 8 'deki verilerle de uyumlu gözükmektedir.

Tablo 11

Belediye Meclisi ve Faaliyetleri Hakkında Bilgi Düzeyi

\begin{tabular}{|l|c|c|c|c|c|c|}
\hline \multirow{2}{*}{$\begin{array}{l}\text { Belediye Faaliyetleri Hakkında Bilgi } \\
\text { Edinme Yolları }\end{array}$} & \multicolumn{2}{|c|}{ Katılıyorum } & \multicolumn{2}{c|}{$\begin{array}{c}\text { Kısmen } \\
\text { Katılıyorum }\end{array}$} & \multicolumn{2}{c|}{ Katılmıorum } \\
\cline { 2 - 7 } & Frekans & Yüzde & Frekans & Yüzde & Frekans & Yüzde \\
\hline $\begin{array}{l}\text { Belediyenin stratejik planı hakkında bilgim } \\
\text { var. }\end{array}$ & 26 & 53,1 & 6 & 12,2 & 17 & 34,7 \\
\hline $\begin{array}{l}\text { Belediyenin her yıl yayınladığı faaliyet } \\
\text { raporunu takip ederim. }\end{array}$ & 31 & 63,3 & 7 & 14,3 & 11 & 22,4 \\
\hline Belediyenin vizyonu hakkında bilgim var. & 35 & 71,4 & 7 & 14,3 & 7 & 14,3 \\
\hline Belediye faaliyetleri hakkında bilgim var. & 41 & 83,7 & 5 & 10,2 & 3 & 6,1 \\
\hline $\begin{array}{l}\text { Mecliste görüşülecek konular hakkında } \\
\text { bilgim var. }\end{array}$ & 35 & 71,4 & 0 & 0 & 14 & 28,6 \\
\hline $\begin{array}{l}\text { Belediye meclis gündemini düzenli takip } \\
\text { ederim. }\end{array}$ & 34 & 68 & 3 & 6 & 13 & 26 \\
\hline Belediye kararlarını düzenli takip ederim. & 36 & 75 & 3 & 6,3 & 9 & 18,8 \\
\hline $\begin{array}{l}\text { Belediye meclisinin görev ve yetkilerini } \\
\text { biliyorum. }\end{array}$ & 37 & 80,4 & 3 & 6,5 & 6 & 13 \\
\hline
\end{tabular}

Danışma ve aktif katılım açısından bakıldığında ise katılımcıların en fazla desteklediği görüş, meclis üyelerinin doğrudan seçmene hesap verebilmesi $(\% 89,6)$ ve şehrin sorunları için referandum yapılarak halka sorulmasıdır $(\% 83,7)$. Mevcut durumda belediyelerde kullanılan isteğe bağlı referandum ve kamuoyu araştırmaları ancak danışma şeklinde katılıma imkân vermektedir.

Tablo 12

Belediyelerde Danışma ve Aktif Katılıma İlişkin Görüşler

\begin{tabular}{|l|c|c|c|c|c|c|}
\hline \multirow{2}{*}{$\begin{array}{l}\text { Danışma ve Aktif Katılım Yolları } \\
\text { Hakkındaki İfadeler }\end{array}$} & \multicolumn{2}{|c|}{ Katılıyorum } & \multicolumn{2}{c|}{$\begin{array}{l}\text { Kısmen } \\
\text { Katılıorum }\end{array}$} & \multicolumn{2}{c|}{ Katılmıorum } \\
\cline { 2 - 7 } & Frekans & Yüzde & Frekans & Yüzde & Frekans & Yüzde \\
\hline $\begin{array}{l}\text { Meclis üyeleri doğrudan seçmene hesap } \\
\text { vermelidir. }\end{array}$ & 43 & 89,6 & 1 & 2,1 & 4 & 8,3 \\
\hline $\begin{array}{l}\text { Şehrin belli sorunları için referandum } \\
\text { yapılarak halka sorulmalıdır. }\end{array}$ & 41 & 83,7 & 1 & 2 & 7 & 14,3 \\
\hline $\begin{array}{l}\text { Belediye hizmetlerine gönüllü katılmak } \\
\text { isterim. }\end{array}$ & 38 & 77,6 & 7 & 14,3 & 4 & 8,2 \\
\hline Belediyeyi sosyal medyadan takip ederim. & 37 & 75,5 & 1 & 2 & 11 & 22,5 \\
\hline Çözüm masasına ulaşma yollarını biliyorum. & 36 & 75 & 5 & 10,4 & 7 & 14,6 \\
\hline E-belediye hizmetlerini sıkça kullanırım. & 29 & 59,2 & 1 & 2 & 19 & 38,8 \\
\hline $\begin{array}{l}\text { Belediye bütçesinin hazırlanmasında } \\
\text { seçmene danışılmalıdır. }\end{array}$ & 28 & 58,3 & 6 & 12,5 & 14 & 29,2 \\
\hline Kent konseyleri hakkında bilgim var. & 23 & 48,9 & 3 & 6,4 & 21 & 44,7 \\
\hline
\end{tabular}


Türkiye'de belediyelerde hukuki altyapıs1 ${ }^{5}$ da bulunan gönüllü katılım konusunda da ankete katılanların ciddi bir desteği bulunmaktadır. Katılımcıların \%77,6’s1 ("kısmen katılıyorum" seçeneğini işaretleyenlerle birlikte \%91,9) belediye hizmetlerine gönüllü katılmak istediğini belirtmiştir.

Belediye meclis toplantılarına katılanların 3/4'ünden fazlası $(\% 75,5)$ belediyeyi sosyal medyadan takip etmektedir. Anketi cevaplayanların sosyal medya yoluyla belediyeye hangi düzeylerde katılım gösterdikleri ise bu araştırmanın kapsamı dışında kalmaktadır. Ancak bu bağlamda yapılan araştırma sonuçlarına göre belediyelerde sosyal medya ağırlıklı olarak bilgi verme ve tanıtım gibi tek yönlü iletişim için kullanılmaktadır (bkz. Sobacı ve ark., 2015). Belirtmek gerekir ki sosyal medyanın hem ulusal politikalara hem de yerel yönetimlere aktif katılımı artırdığı ampirik olarak desteklenmektedir (Harode-Rosario ve ark. 2018; Zhang ve ark., 2010). Yerel yönetimler için sosyal medyanın oluşturduğu alan sadece katılımla sınırlı kalmayıp, etkinlik ve üretkenliğin iyileştirilmesi, yerel kamu hizmetlerin nitelikli hale getirilmesi ve yerel demokrasinin güçlendirilmesi gibi konularda da yeni imkanlar sunmaktadır (Sobac1, 2016). Sosyal medyanın aktif katılımı artırıcı rolü yerel yönetimler için bir firsat olarak değerlendirilebilir.

Sosyal medyanın yanında hem bilgi edinme hem de kısmen aktif katılıma imkân veren dijital katılım yollarından birisi de e-belediyecilik hizmetleridir. E-belediyecilik dijital ortamda belediye hizmetlerine ulaşma, belediye faaliyetleri hakkında bilgilenme ve işlem yapabilme imkânı sağlamaktadır. Hemşehrilerin internet yoluyla belediye hizmet süreçlerine katılımını sağlayan e-belediye hizmetlerini ankete katılanların yaklaşık \%60’ı sıkça kullandığını ifade etmektedir. Sosyal medya takibi ile karşılaştırıldığında e-belediyecilik hizmetlerine olan ilginin düşük kaldığı görülmektedir. Yine de farklı büyükşehir belediyelerinin e-belediyecilik hizmetlerinden haberdar olma ve bu hizmetleri kullanma düzeyini ölçen ampirik araştırmalarla karşılaştırınca, belediye meclis toplantılarına katılanların e-belediyecilik hizmetlerini kullanma düzeyleri daha yüksektir (bkz. Gürler Hazman, 2005; Negiz, 2011). Örneğin İzmir Büyükşehir Belediyesi'nin e-belediyecilik hizmetlerine ilişkin bir araştırmaya katılanların \%63,2'si e-belediyecilik hizmetlerinden haberlerinin olmadığını ifade etmektedir (Çakır, 2017: 10). Kocaeli Büyükşehir Belediyesi için yürütülen benzer bir araştırmaya katılanların \%22,7 e-belediyecilik hizmetleri hakkında bilgi sahibi olduğunu belirtirken, \%89,3’ü herhangi bir e-belediyecilik hizmetinden yararlanmadığını belirtmiştir (Sayımer, 2019).

Katılımcıların 3/4'ü $(n=36)$ çözüm masasına ulaşma yollarını bildiğini ifade etmiştir. Çözüm masası, belediye hizmetleriyle ilgili talep, şikâyet ve önerilerin alındığı ve bu yolla hemşehrilerin hizmet süreçlerine katıldığı bir mekanizmadır. Çözüm masasına ulaşma yollarıyla ilgili farkındalığın yüksek olması bu bakımdan önemlidir.

Yerel halkın kentsel politikalara aktif katılımını sağlayan uygulamalardan birisi de katılımcı bütçelemedir. Katılımcı bütçe hakkında Türkiye' de yasal düzenleme bulunmamakla birlikte bazı yerel yönetim kuruluşlarında uygulama örnekleri bulunmaktadır. Araştırma kapsamında belediye meclis toplantılarını izleyenlerin yaklaşık \%60'ı (n=28) belediye bütçesinin oluşturulmasında seçmenlere danışılması gerektiği fikrini desteklemektedir.

5 Belediye hizmetlerine gönüllü katılımla ilgili temel düzenlemeler, 5393 sayılı Belediye Kanunu'nun 77. maddesi ve 2005 yılında kabul edilen İl Özel İdaresi ve Belediye Hizmetlerine Gönüllü Katılım Yönetmeliğidir. 
Belediyelerde gönüllü katılım ve müzakereci demokrasinin yerleşmesinde önemli bir role sahip olan kent konseyleri hakkında katılımcıların yeteri kadar bilgisinin bulunmadığı görülmektedir. Katılımcıların \%48,9’u (n=23) kent konseyleri hakkında bilgi sahibi olduğunu ifade etmiştir. Kentsel yönetişim ve katılımın temel kurumlarından olmasına rağmen, diğer aktif katılım yollarına göre kent konseylerinin bilinirliğinin düşük olmasının temel nedeni olarak Sakarya ilinde kent konseyinin yeteri kadar aktif olmaması ve kurumsallaşamamasının etkili olduğu düşünülmektedir.

\section{Tartışma}

$\mathrm{Bu}$ araştırma neticesinde ilk olarak Sakarya ili özelinde belediye meclis toplantılarına dışarıdan katılan kişilerin demografik özellikleri belirlenmiştir. Buna göre, meclis toplantılarına genellikle orta yaş grubunda yer alan, eğitim düzeyi yüksek, ortalama gelire sahip, şehirde uzun süredir yaşayan yani yerleşik durumda olan ve ağırlıklı olarak serbest meslek ile meşgul olanlar katılmaktadır. \%86'sı erkek olan katılımcılar sıklıkla ve/veya düzenli olarak meclis toplantılarını izlemektedir. Ayrıca bu kişilerin yerel ve ulusal siyasete olan ilgilerinin, oy verme ve parti üyeliği biçimindeki siyasal katılma davranışlarının da yüksek olduğu görülmektedir.

Meclis toplantılarına katılanlar çoğunlukla ya meclis gündemini takip etmek ya da bilgilenmek amacıyla katılmaktadır ki bu da beklenen bir sonuçtur. Yasal olarak dışarıdan meclis toplantılarına katılanların söz hakkı istemesi, oy hakkı ve tartışmalara nasıl katılabilecekleriyle ilgili düzenlemeler yetersizdir. $\mathrm{Bu}$ nedenle, toplantılara dişarıdan katılanlar hukuki yönden pasif izleyiciler olarak düşünülmüştür.

Katılımcılar, belediye meclis toplantılarında bulunmanın hemşehrilik bilincini yükselttiğini düşünmektedir. Yani meclislere dinleyici olarak katılmak bile bireylerin şehre olan bağlılığını artırmaktadır. Ancak belirtmek gerekir ki, anketlerin yapılması için düzenli olarak meclislere yapılan ziyaretlerde katılım düzeyinin oldukça düşük olduğu gözlenmiştir. Çoğu kez toplantılarda meclis üyeleri ve belediye bürokratları dışında yerel halktan katılımcıya rastlanmamıştır. Katılımcıların önemli bir bölümünün $(\% 68$ civarında) bir siyasal parti üyesi olması, siyasal partileri temsilen orada bulundukları izlenimi oluşturmaktadır.

Belediye meclislerinde kararlar genellikle ihtisas komisyonları ve parti grupları içerisinde formüle edilmektedir. Meclis oylamalarında da parti grupları genellikle ortak hareket ettiğinden gündem üzerinde fazla tartışma olmadan karar alınmaktadır (Oktay, 2013: 133; Uyan Semerci, 2015). Belediye başkanı ile meclis çoğunluğu aynı partiden olması durumunda, meclisler daha da zayıflamakta ve onay makamına dönüşmektedir. Ayrıca belediye meclis toplantılarına yapılan ziyaretlerde gündem maddelerinin büyük çoğunluğunun imar değişikliklerini içerdiği gözlenmiştir. Meclis gündeminde konu çeşitliliğinin olmaması ve imar sorunlarına yoğunlaşmasının da toplantılara dışarıdan geleceklerin ilgisini zayıflattığı düşünülmektedir. Belediye başkanı-meclis ilişkilerinin düzenleniş biçimi, meclislerin oluşumu ve işleyişiyle ilgili sorunlar şehir halkının meclis toplantılarına yönelik ilgisini azaltan diğer faktörlerdir.

Belediyelerin seçilmiş organlarının atamayla belirlenmesi fikrinin yüksek oranda destek bulmaması ve belediye meclislerinin demokrasi kültürünün yerleşmesinde önemli bir kurum olarak görülmesi meclis toplantılarına dışarıdan takip etmek için katılan 
yurttaşlarda yerel demokrasi algısının güçlü olduğunu göstermektedir. Yerel seçilmiş organların meşruiyeti de katılımcılar nezdinde yüksektir.

$\mathrm{Bu}$ çalışmanın diğer bir araştırma sorusu da katılımcıların bilgilenme, danışma ve aktif katılımdan oluşan siyasal katılım boyutlarına ilişkin görüşlerinin ölçülmesidir. $\mathrm{Bu}$ bağlamda, belediyenin stratejik planı, faaliyet raporları, vizyonu, yetki ve görevleri ve yürüttüğü faaliyetlere ilişkin katılımcıların bilgi düzeylerinin genel olarak yüksek olduğu görülmüştür. Meclis toplantılarına dinleyici olarak katılmanın doğasına uygun olarak katılımcıların belediyenin politik ve idari süreçlerine olduğu kadar yerel ve ulusal siyasi olaylarla ilgili de bilgi sahibi oldukları anlaşılmaktadır. Ayrıca belediyelerde siyasal katılmanın danışma ve aktif katılım boyutlarına yönelik katılımcıların beklentileri de oldukça yüksek çıkmıştır.

\section{Sonuç}

Bu çalışmada, literatürde fazla üzerinde durulmamakla birlikte alternatif bir kentsel katılım yolu olan belediye meclis toplantılarına halkın ilgisi ve katılımı Sakarya ili özelinde incelenmiştir. Sakarya büyükşehir belediyesi ve kent merkezindeki ilçe belediyeleri doğrudan ziyaret edilerek istekli katılımcılara anket uygulanmak suretiyle veri toplanmıştır. Böylece belediye meclis toplantılarına katılanların demografik özellikleri ve katılım nedenleri, yerel demokrasi algıları ve siyasal katılımın farklı boyutlarına ilişkin görüşleri araştırılmıştır. Araştırma bulgularının analizi ve yorumunun verinin toplandığı il ve belediye meclisleriyle sınırlı olduğu belirtilmelidir.

Araştırma sonucunda meclis toplantılarına dinleyici olarak yerel halkın dahil olması şeklinde siyasal katılım davranışını gösteren bireylerin demografik özellikleri ve siyasal eğilimleri belirlenmiştir. Ayrıca katılımcıların genellikle gündemi takip etmek, kararları izlemek ve bilgi edinmek amacıyla toplantılara katıldıkları tespit edilmiştir. Katılımcıların büyük çoğunluğunun bir siyasal partiye üye olmas1, bu kişilerin doğrudan bir partinin temsilcisi olarak mı yoksa kendi istekleri doğrultusunda mı katıldıkları sorusunu akla getirmektedir. Ancak ankette katılımcıların üye oldukları siyasal partilerle ilişkilerine dair sorular bulunmadığından bu konuda net bir cevap vermek mümkün değildir. Siyasal parti temsilcisi olma durumunun, gelecek çalışmalarda dikkate alınması ihtiyacı ortaya çıkmaktadır.

Meclis toplantılarına katılanların verdiği cevaplar incelendiğinde, toplantılara katılımın yerel demokrasi ve şehre bağlılıklarını güçlendirdiği, hemşehrilik bilincini artırdığı düşünülmektedir. Bu bulgu yerel demokrasinin güçlendirilmesi için meclis toplantılarına yönelik yerel kamuoyunun ve hemşehrilerin ilgisini artırıcı yeni düzenlemelerin ve politikaların geliştirilmesi ihtiyacını ortaya çıkarmaktadır. Meclis toplantılarına yönelik ilginin artırılması için toplantı zamanı, gündem maddeleri, alınan kararların özeti gibi bilgilerin dijital ve mobil iletişim yolları kullanılarak şehir halkına daha hızlı ve etkili bir şekilde iletilmesi önerilebilir. Bu kapsamda kullanıcı dostu bir yaklaşımla hazırlanan içerikler e-posta, akıllı telefon mesajları ve sosyal medya kanalları gibi yeni iletişim teknolojileri kullanılarak oluşturulan bilgi ağları yoluyla hemşehrilere ulaştırılmalıdır.

Ayrıca belediye meclislerinin güçlendirilmesi, karar ve politikaların tasarımında yurttaşların katılımını da gözeten müzakere mekanizmalarının kullanılması ve meclis toplantılarına dışarıdan katılımcı olanlara söz hakkı verilmesi gibi hususlara ilişkin hukuki 
ve kurumsal düzenlemelerin yapılması önemli görülmektedir. Bu gibi düzenlemelerin belediye meclislerine dinleyici olarak katılanların sayısının artmasına, meclislerin daha müzakereci bir organa dönüşmesine ve meclis toplantılarına yönelik kamuoyunun ilgisinin artmasına katkı yapacağı düşünülmektedir.

Belediye meclis toplantılarını izleyen katılımcıların, pasif olarak toplantıları takip etmenin yanında referandum, katılımcı bütçeleme ve yerel hizmetlere gönüllü katılım gibi aktif yurttaşlık eksenindeki katılım yollarına yönelik algısının da yüksek olduğu anlaşılmaktadır. $\mathrm{Bu}$ bulgular, belediyelerin aktif katılımı destekleyici kurumsal mekanizmalar oluşturmasının demokratik katılım kültürü üzerinde olumlu etkileri bulunabileceğini göstermektedir. Bu durum, kamusal eylemlere karşı bir uyanık olma, hazır bulunma halini ifade etmektedir. Rosanvallon'a göre (2008: 33-34) "uyanık olma" (vigilance) durumu hükümet eylemlerinin sürekli olarak ve yakından gözetimini kapsar. Bu yönüyle siyasal katılmanın özel bir biçimi olup göz ardı edilebilecek bir pasiflik değil, aksine eyleme hazır olmayı ifade eder. Bu çalışmaya uyarlandığında belediye meclisi toplantılarına katılanların bir yerel kamusal otorite olan belediyenin gündemini, eylem ve faaliyetlerini yakından ve sürekli izledikleri, gözetim altında tuttukları anlaşılmaktadır. Bilgilenme düzeyi, aktif katılım türlerine olan ilgileri ve yerel demokrasi algılarının yüksek olması meclis toplantılarına katılan yurttaşların gelecekte diğer katılım davranışlarını da gösterebileceklerine işaret etmektedir.

Ancak belirtmek gerekir ki bu çalışmanın sonuçları Sakarya ili özelinde seçilen belediyelerle sınırlıdır. Nüfus ve ölçek olarak daha büyük olan kentlerde, siyasal olarak daha farklı yapıya sahip olan belediyelerde yeni sonuçlara ulaşılabileceği düşünülmektedir. $\mathrm{Bu}$ nedenle, benzer araştırmaların farklı siyasal kültüre, gelişmişlik düzeyine, nüfus ve ölçeğe sahip olan başka kentlerde de tekrarlanması önerilmektedir. Yukarıda yer verilen argümanların farklı siyasal partilerin hâkim olduğu belediyelerde test edilmesi karşılaştırmalı çalışmalar açısından da önemli katkılar sağlayacaktır. Farklı büyüklükteki kentlerde daha geniş bir örneklem grubu oluşturulduğunda çeşitli siyasal ve demografik değişkenler ile katılımcıların meclis toplantılarını izleme, yerel demokrasi algıları ve katılım yollarına ilişkin görüşleri arasındaki ilişkiler daha derinlemesine analiz edilebilecektir. Böylece Türkiye’de yerel siyasal katılımın özellikle bilgilenme boyutuyla ilgili daha kapsamlı çıkarımlarda bulunmanın mümkün hale geleceği düşünülmektedir.

Hakem Değerlendirmesi: Dış bağımsız.

Çıkar Çatışması: Yazarlar çıkar çatışması bildirmemiştir.

Finansal Destek: Yazarlar bu çalışma için finansal destek almadığını beyan etmiştir.

Peer-review: Externally peer-reviewed.

Conflict of Interest: The authors have no conflict of interest to declare.

Grant Support: The authors declared that this study has received no financial support.

\section{Kaynakça/References}

Aksu, H. \& Kurtuluş, H. (2011). Yerel Temsil ve Katılım Açısından Sivas Belediye Meclisi. Türk İdare Dergisi, (470), 113-132.

Alkan, H. \& Çiftçioğlu, H. (2007). Yerel Siyasette Belediye Meclisi ve Siyasi Parti Örgütleri: Göksun Örneği. Kocaeli Üniversitesi Sosyal Bilimler Enstitüsü Dergisi, 14(2), 1-27.

Altunışık, R., Coşkun, R., Bayraktaroğlu, S. \& Yıldırım, E. (2012). Sosyal Bilimlerde Araştırma Yöntemleri SPSS Uygulamalı. 7. Baskı, Sakarya: Sakarya Kitabevi. 
Arıkboğa, E., Oktay, T., \& Yılmaz, N. (2007). Yeniden Yapılanma Sonrasında Belediye Meclisleri: Istanbul Örneği. İstanbul: Beta.

Arıkboğa, E. (2009). Ölçek Reformunun Büyükşehir Belediye Meclislerindeki Temsil Adaletine Olumlu Etkileri. İçinde Ulusal Kalkınma ve Yerel Yönetimler: 4. Ulusal Yerel Yönetimler Sempozyumu Bildirileri. Ankara: Türkiye ve Orta Doğu Amme İdaresi Enstitüsü Yayınları, s. 737-754.

Arıkboğa, E. (2010). Yerel Yönetimlerde Katılım ve Meclislerin Rolü. İçinde Yerel Yönetim Anlayışında Yeni Yaklaşımlar Sempozyumu. İstanbul: Okan Üniversitesi Yayınları, s. 193-209.

Arıkboğa, E. (2014). Büyükşehir Belediye Meclislerindeki Temsil Adaletsizliğinin Coğrafi ve Siyasi Görünümleri. Marmara Üniversitesi Siyasal Bilimler Dergisi, 2(2), 35-61.

Arnstein, S. R. (1969), “A Ladder of Citizen Participation”, Journal of the Royal Town Planning Institute, April, s. 1-6.

Atkinson, R. \& Moon, G. (1996). Urban Policy in Britain: the City, the State and the Market. Hampshire: Macmillan Press.

Azaklı, S., \& Özgür, H. (2005). Belediye Organları ve organlar arası ilişkiler: Başkan, meclis ve encümen. İçinde H. Özgür \& M. Kösecik (Ed.), Yerel Yönetimler Üzerine Güncel Yazılar-I: Reform. Ankara: Nobel Yayın Dağıtım, s. 297-319.

Bulut, Y. \& Tanıyıc1, Ş. (2008). Türkiye'de Belediye Meclis Üyelerinin Temsil Ediciliği: Erzincan Örneği. Dumlupınar Üniversitesi Sosyal Bilimler Dergisi, (21), 171-194.

Cabada, L. (2013). "Parties with no Members?": How to Ensure Political Participation in East Central Europe?. Democracy in Transition: Political Participation in European Union, Demetrieu, K. N. (Ed.), Heidelberg: Springer, s. 77-94.

CoE (2009). Code of Good Practice for Civil Participationin the Decision-Making Process. CONF/PLE(2009) CODE1, Conference of INGOs of the Council of Europe, https://www.eesc.europa.eu/resources/docs/codeof-good-pratice-for-civil--participation-in-the-decision-making-process-en.pdf, (Erişim Tarihi: 12.04.2020).

Creighton, J. L. (2005), The Public Participation Handbook, San Francisco: Jossey-Bass.

Çakır, C. (2017). İzmir Büyükşsehir Belediyesinde E-Belediye Uygulamaları ve vatandaşın Farkındalığı. Hukuk ve İktisat Araştırmaları Dergisi, 9(1), 1-12.

Çelik, A. \& Uluç, A. V. (2009). Yerel Siyasette Temsil Üzerine Bir Çalışma: Şanlıurfa Örneği. İstanbul Üniversitesi Siyasal Bilgiler Fakültesi Dergisi, (41), 215-231.

Çitci, O. (1989). Yerel Yönetimlerde Temsil: Belediye Örneği. Ankara: Türkiye ve Orta Doğu Amme İdaresi Enstitüsü Yayınları.

Dalton, R. J. \& Klingeman, H.-D. (2011). Overview of Political Behavior: Political Behavior and Citizen Politics. In R. E. Goodin (Ed.), The Oxford handbook of political science (pp. 322-345). Oxford University Press.

DeSantis, V. S. \& Renner, T. (2002). City government structures: An attempt at clarification. State and Local Government Review, 34 (2), 95-104.

Erder, S. \& İncioğlu, N. (2008). Türkiye’de Yerel Politikanın Yükselişi: İstanbul Büyükşehir Belediyesi Örneği, 1984-2004. İstanbul: İstanbul Bilgi Üniversitesi Yayınları.

Erdoğan, E. (2015). Büyükșehir Belediye Meclis Üyelerinin Profilleri Üzerine Bir Çalışma. İçinde P. Uyan Semerci (Ed.), Yerel Demokrasi Sorunsall: Büyükşsehir Belediye Meclisleri Yapısı ve İşleyişi, İstanbul: İstanbul Bilgi Üniversitesi Yayınları, 73-97.

European Parliament (2016). Potential and Challenges of E-Participation in the European Union. Directorate General for Internal Policies. PE 556.949, https:/www.europarl.europa.eu/RegData/etudes/STUD/2016/ 556949/IPOL STU\%282016\%29556949 EN.pdf, (Erişim Tarihi: 12.01.2021).

Güneş, M. (2017). Yerel Demokrasi Tartışması Olarak: Büyükşehir Belediye Meclislerinde Seçim Sistemi ve Temsilde Adalet Sorunu. Siyaset, Ekonomi ve Yönetim Araştırmaları Dergisi, 5(1), 47-61.

Gürler Hazman, G. (2005). Afyonkarahisar Belediyesinde e-Belediye Uygulamaları ve Yerel Farkındalık. Afyon Kocatepe Üniversitesi IIBF Dergisi, 7(2), 65-84.

Hague, R., Harrop, M. \& McCormick, J. (2016). Political Science: A Comparative Introduction. 8th Edition, New York: Palgrave.

Haro-de-Rosario, A., Sáez-Martín, A. \& Caba-Pérez, M. (2018). Using Social Media to Enhance Citizen Engagement with Local Government: Twitter or Facebook?. New Media and Society, 20 (1), 29-49.

http://www.ysk.gov.tr/tr/mahalli-idareler-genel-secimleri-arsivi/2650 (Erişim: 9 Mayıs 2020).

IAP2 (2018) Spectrum of Public Participation, International Association for Public Participation, https://cdn. ymaws.com/www.iap2.org/resource/resmgr/pillars/Spectrum 8.5x11Print.pdf, (Erişim Tarihi: 12.12.2019).

Kocaoğlu, M. (2015). Yerel Yönetimlerde Katılım ve Kültür: Katılımcı Yerel Yönetim Anlayışının Kültürel Temelleri. Konya: Çizgi Kitabevi Yayınları.

Lamba, M. \& Kerman, U. (2016). Kent Konseylerinin Belediye Meclislerinde Gündem Belirlemedeki Etkisi: Antalya, Afyonkarahisar ve Burdur Örneği. Mehmet Akif Ersoy Üniversitesi Sosyal Bilimler Enstitüsü Dergisi, 8(16), 89-106.

Lamprianou, I. (2013). Contemporary Political Participation Research: A Critical Assessment. Democracy in Transition: Political Participation in European Union, Demetrieu, K. N. (Ed.), Heidelberg: Springer, s. 21-42. 
Milbrath, Lester W. ve Goel, L. (1977). Political Participation: How and Why Do People Get Involved in Politics?. Chicago: Rand McNally Collage Publishing.

Negiz, N. (2011). Elektronik Dönüşüm Karşısında Vatandaş Deneyimi: Isparta Belediyesi İncelemesi, Sosyal Ekonomik Araştırmalar Dergisi, 11(21), 499-534.

OECD (2001), Citizens as Partners, Information, Consultation and Public Participation in Policy-Making, Paris.

Oktay, T. (2013), Yerel Siyaset Bağlamında Belediye Meclis Komisyonları: Marmara Bölgesi Örneği, İstanbul: MBB Kültür Yayınları.

Oktay, T. (2016). Yerel Yönetim Reformu Sonrasında Türkiye’de Belediye Meclisleri. İçinde Y. Demirkaya (Ed.), Türkiye’de Yeni Kamu Yönetimi: Yerel Yönetim Reformu, İstanbul: Dünya Yerel Yönetim ve Demokrasi Akademisi Vakfi, s. 355-385.

Rosanvallon, P. (2008). Counter-Democracy: Politics in An Age of Distrust. Goldhammer, A (Çev.), Cambridge: Cambridge University Press.

Schlozman, K. L. (2010). Political Participation. In G. T. Kurian (Ed.), The Encyclopaedia of Political Science (pp. 1260-1263). CQ Press.

Sayımer, İ. (2019). E-Yönetișim Bağlamında Yeni Medya Ortamlarında Belediye-Yurttaş Etkileșimi: Kocaeli İli Örneği. TÜBITAK SOBAG 1001 Proje (117K012), Kocaeli.

Sezik, M. (2017). Yerel Siyasal Aktörlerin Belediyelerde Karar Alma Mekanizmalarına Katılımı: Adıyaman Belediye Meclis Örneği. Birey ve Toplum, 7(14), 65-88.

Sobacı, M. Z. ve Köseoğlu, Ö. (2016). Başkanlık Sistemlerinde Yerel Yönetimler: ABD, Brezilya, Şili, Endonezya ve Güney Kore. Ankara: Seta Yayınları.

Sobacı, M. Z., Köseoğlu, Ö. \& Karkın, N. (2015). Belediyelerde Sosyal Medya: Değişim İçin Yenilikçi Fırsatlar. İstanbul: MBB Kültür Yayınları.

Sobac1, M. Z. (2016). Social Media and Local Governments: An Overview. Social Media and Local Governments Theory and Practice. Sobac1 M. Z. (Ed.) Springer, 3-21.

Tambouris, E., Liotas, N., \& Tarabanis, K. (2007). A Framework for Assessing eParticipation Projects and Tools. İçinde R.H. Sprague (Ed.), Proceedings of the 40th Annual Hawaii International Conference on System Sciences. LosAlamitos, CA: IEEE Computer Society Press, 1-10.

Türeli, N. \& Çağlar, N. (2010). Yerel Yönetimde Kadın Temsili: Isparta ili Örneği. Süleyman Demirel Üniversitesi Vizyoner Dergisi, 2(1), 16-40.

Uçar, A., \& Negiz, N. (2016). Yerelde Kamu Politikalarının Oluşumunda Yönetişim ve Katılımcılık: Isparta İncelemesi. Süleyman Demirel Üniversitesi Sosyal Bilimler Enstitüsü Dergisi, (CİEP Özel Sayıs1), 788-819.

United Nations (2014). E-Government Survey 2014, E-Government for the Future We Want. New York: UN Department of Economic and Social Affairs, https://publicadministration.un.org/egovkb/Portals/egovkb/ Documents/un/2014-Survey/E-Gov Complete_Survey-2014.pdf, (Erişim Tarihi: 12.01.2021).

Uyan Semerci, P. (Ed.). (2015). Yerel Demokrasi Sorunsalı: Büyükşsehir Belediye Meclisleri Yapısı ve Iş̧leyişsi. İstanbul: İstanbul Bilgi Üniversitesi Yayınları.

Wirtz, Bernd W., Daiser, P. \& Binkowska, B. (2018). E-participation: A Strategic Framework, International Journal of Public Administration, 41(1), 1-12.

Yıldırım, U., Öner, Ş., Aksu, H., \& Tatlı, S. M. (2011). Yerel Temsil ve Katılım Bağlamında Belediye Meclisleri: Kahramanmaraş ve Sivas Örnekleri. Mustafa Kemal Üniversitesi Sosyal Bilimler Enstitüsü Dergisi, 8(15), 507-530.

Yıldırım, U., Gül, Z., Akın, S., Kılaç, S. \& Kıraç, Y. (2015). Türkiye'de Belediye Meclislerinin Temsil Ediciliği Siirt Örneği. Elektronik Sosyal Bilimler Dergisi, 14(54), 278-306.

Zeren, H. E., \& Özmen, A. (2010). Halkın Belediye Faaliyetlerine Katılma Duyarlılı̆̆ 1 ve Hizmet Memnuniyeti: Karaman Belediyesi Örneği. KMÜ Sosyal ve Ekonomik Araştırmalar Dergisi, 12(19), 165-173.

Zhang, W., Johnson, T.J., Seltzer, T. \& Bichard, S. L. (2010). The Revolution Will be Networked: The Influence of Social Networking Sites on Political Attitudes and Behavior. Social Science Computer Review, 28 (1), $75-92$. 